\title{
Medical students' perception of the learning environment at King Saud University Medical College, Saudi Arabia, using DREEM Inventory
}

This article was published in the following Dove Press journal:

Advances in Medical Education and Practice

17 March 2017

Number of times this article has been viewed

\author{
Mona M Soliman ${ }^{1,2}$ \\ Kamran Sattar ${ }^{2}$ \\ Sami Alnassar ${ }^{3}$ \\ Faisal Alsaif ${ }^{4}$ \\ Khalid Alswat ${ }^{5}$ \\ Mohamed Alghonaim 6 \\ Maysoon Alhaizan ${ }^{7}$ \\ Nawaf Al-furaih ${ }^{7}$ \\ 'Department of Physiology, \\ 2Department of Medical Education, \\ ${ }^{3}$ Department of Surgery, College \\ of Medicine, King Saud University, \\ ${ }^{4}$ Department of Surgery, King Saud \\ University Medical City, ${ }^{5}$ Department \\ of Internal Medicine, ${ }^{6}$ Department of \\ Medicine, ${ }^{7}$ College of Medicine, King \\ Saud University, Riyadh, Saudi Arabia
}

Correspondence: Mona M Soliman Department of Physiology, King Saud University, College of Medicine, P.O. Box 29825 (29), Riyadh I I46I, Saudi Arabia Tel +966 I I47 019|

Email msoliman I@ksu.edu
Background: The students' perception of the learning environment is an important aspect for evaluation and improvement of the educational program. The College of Medicine at King Saud University (KSU) reformed its curriculum in 2009 from a traditional to a system-oriented hybrid curriculum.

Objective: The objective of the present study was to determine the perception of the second batch (reformed curriculum) of medical graduates about the educational environment at the College of Medicine, KSU, using the Dundee Ready Education Environment Measure (DREEM) scale.

Methods: The fifth year medical students were asked to evaluate the educational program after graduation in May 2014. The questionnaire was distributed to the graduate students electronically. The DREEM questionnaire consisted of 50 items based on Likert's scale; and five domains, namely, students' perceptions of learning, perceptions of teachers, academic self-perceptions, perceptions of atmosphere, and social self-perceptions. Data were analyzed using SPSS.

Results: A total of 62 students participated in the study. The score for students' perception of learning among medical students ranged from 2.93 to 3.64 (overall mean score: 40.17 ). The score for students' perception of teachers ranged from 2.85 to 4.01 (overall mean score: 33.35 ). The score for students' academic self-perceptions ranged from 3.15 to 4.06 (overall mean score: 28.4). The score for students' perception of atmosphere ranged from 2.27 to 3.91 (overall mean score: 41.32). The score for students' social self-perceptions ranged from 2.85 to 4.33 (overall mean score: 24.33). The general perceptions of the students in all five sub-scales were positive. Conclusion: The overall student's perception about the educational environment was satisfactory. This study was important to evaluate the students' perception of the learning environment among medical graduates of the reformed curriculum and provided guidance on areas of improvement in the curriculum.

Keywords: medical students, perception, learning environment, DREEM inventory, Saudi Arabia

\section{Introduction}

The World Federation for Medical Education emphasized the learning atmosphere as one of the aims for the appraisal of medical education programs. ${ }^{1}$ It is extensively approved by medical educators that the effects of the educational atmosphere, both academic and clinical, are significant determinants of medical students' attitudes, knowledge, skills, progression, and behaviors., ${ }^{2,3}$ Appraisal of the educational environment at both academic and clinical sites is significant to the provision for student-centered 
curriculum of an extraordinary quality. ${ }^{4}$ During the process of conducting students' evaluation, an all-inclusive, valid, and reliable instrument is indispensably required.

For a very long period, the academics have endeavored to outline and evaluate the medical education environment. ${ }^{5-11}$ In this pursuit, the most extensively used instrument is unquestionably the Dundee Ready Education Environment Measure (DREEM). ${ }^{12}$ The DREEM is a 50-item measure of students' perceptions of their learning environment, with five scales score recording the perception of learning, perception of teachers, academic self-perception, perception of atmosphere, and social self-perception. The DREEM has been demonstrated as an internationally useful tool in a variety of health care settings. ${ }^{13}$ Nowadays, there has been a mounting interest among health care professional institutes, including College of Medicine, King Saud University (KSU), to get an in-depth evaluation of the learning environment.

The objective of the present study was to determine the perception of the second batch of medical graduates about the educational environment at the College of Medicine, KSU, which in turn would pave the way to evaluate weaknesses (if any) in the relatively new modified curriculum (systemoriented hybrid curriculum), with a view to bring together the required changes. This new and modified curriculum enables the college in cooperation with the Department of Medical Education to have an advanced system of teaching and training of undergraduate medical students. This allows students to actively participate in teaching sessions, such as problem-based learning in small groups, addressing the true integration of basic and clinical medical science subjects. Previously, before the advent of this new modified curriculum, the students were taught according to the old, traditional curriculum, which typically involved a teacher providing facts to students with a focus on a specific body of acquaintance to be transferred to students. The old curriculum was dependent comprehensively on memorization of fact.

We used an easy-to-use device for evaluating the learning environment, that is, DREEM scale, which has been validated and used worldwide as an investigative inventory for measuring the educational environment. This inventory has been usefully applied to medical schools in Europe, Africa, Asia, and America. Medical and allied health educationalists across places and educational backgrounds have extensively used the DREEM scale to evaluate educational climate. ${ }^{12}$ The DREEM is globally recognized as a valuable tool to deliver feedback on the strengths and weaknesses of the educational climate,${ }^{14}$ as it pinpoints areas of concern for the majority of students that might be involuntarily ignored by educationalists.

\section{Methods}

The participants were asked to evaluate the educational program after graduation in May 2014. The DREEM questionnaire was distributed to all participating students electronically.

\section{Study instrument}

The perceptions of participating students in this study were evaluated using the DREEM in English language, which is a validated scale. The development and validation of the DREEM have been reported. ${ }^{15}$

DREEM consists of five sub-scales and they are as follows:

1) Students' perceptions of learning (SPoL) - 12 items; maximum score is 60 ;

2) Students' perceptions of teachers (SPoT) - 11 items; maximum score is 55 ;

3) Students' academic self-perceptions (SASP) - 8 items; maximum score is 40 ;

4) Students' perceptions of atmosphere (SPoA) - 12 items; maximum score is 60 ;

5) Students' social self-perceptions (SSSP) - 7 items; maximum score is 35 .

The DREEM measured the following five above-defined sub-scales: the SPoL, SPoT, SASP, SPoA, and SSSP. All participating students completed the DREEM, and it was noted that participants took around five to seven minutes to complete. The DREEM questionnaire consisted of 50 items based on Likert's scale; and five domains, namely SPoL, SPoT, SASP, SPoA, and SSSP.

\section{Research participants}

The total number of students graduated in the year 2014 was 245 , and all of these medical students were contacted through their emails and were requested to participate in this study. Of them, $62(25.3 \%)$ fifth year medical students agreed to participate in this study.

\section{Settings}

This study was conducted at the College of Medicine, KSU, during the academic year 2014-2015.

\section{The method of data collection}

All participants recorded their responses for the DREEM scale anonymously. This also included a written consent from the participants. The Department of Medical Education, College of Medicine, KSU approved this study. All participants were sent two reminder emails (one week apart) after the first request of the survey. 


\section{Data analysis}

The data obtained from the study were entered into Microsoft Excel 2007 and analyzed using IBM SPSS Program. We used one-way analysis of variance (ANOVA) to analyze the difference in the mean score of the males and females. A $P$-value of $<0.05$ was considered to be statistically significant.

\section{Results}

A total number of 62 medical students in their fifth year of their study from the College of Medicine, KSU participated in this study. Of these, 33 (53.3\%) were males and 29 (46.7\%) were females. The overall score from all five sub-scales of DREEM was $171.57 / 250$. The general perceptions of the students in all five sub-scales were positive.

\section{Students' perceptions of learning}

In the SPoL sub-scale, there were 12 items used (Table 1). The score for SPoL among medical students' ranged from 2.93 to 3.64. The overall mean \pm standard deviation (SD) was $3.34 \pm 0.17$. An overall mean score of 12 items about SPoL was 40.17 of 60 , which showed a good perception of the fifth year medical students about teaching.

The students' responses showed that the teaching encouraged them to participate in classroom as $54.9 \%$ agreed (9.7\% strongly agreed and $45.2 \%$ agreed). Most of the students (56.5\%) reported that "the teaching encourages me to be an active learner"; while $30.6 \%$ of the students sometimes feel that teaching encourages them to be an active learner. Furthermore, most of the students (56.5\%) agreed that learning objective of the course was clear during teaching. But $27.5 \%$ of the students reported that the current teaching was too teacher-centered (Table 1). There are no statically significant differences in 12 items used as no group response difference was observed between males and females of fifth year.

\section{Students' perceptions of teachers}

In the SPoT sub-scale, there were 11 items used (Table 2). The score of SPoT ranged from 2.85 to 4.01 . The overall mean $\pm S D$ was $3.39 \pm 0.37$. An overall mean score of 11 items (67.44\%) about SPoT was 37.35 of 55. This showed a good perception about teachers among fifth year medical students. Most of fifth year students, $80.7 \%$ (24.2\% strongly agree and $56.5 \%$ agree), reported that teachers are knowledgeable about the subject matter. In this study, the mean score was 4.01, no group difference was found between males and females as the $F$-value (0.24) and $P$-value (0.62) were recorded. However, $54.8 \%$ of the students reported that sometime teachers ridicule and have fun with students in the classroom, and the rest of the questions about teacher had a good mean score (Table 2).

\section{Students' academic self-perception}

The SASP sub-scale included eight items (Table 3). The score of SASP among medical students ranged from 3.09 to 4.03 . The overall mean $\pm \mathrm{SD}$ was $3.55 \pm 0.31$. All eight questions

Table I Students' perception of learning

\begin{tabular}{|c|c|c|c|c|c|c|c|}
\hline Questionnaire & Mean \pm SD & $\begin{array}{l}\text { Strongly } \\
\text { agree, } \\
\text { n (\%) }\end{array}$ & Agree, n (\%) & $\begin{array}{l}\text { True } \\
\text { sometimes, } \\
\text { n (\%) }\end{array}$ & $\begin{array}{l}\text { Disagree, } \\
\text { n (\%) }\end{array}$ & $\begin{array}{l}\text { Strongly } \\
\text { disagree, } \\
\text { n (\%) }\end{array}$ & $\begin{array}{l}\text { F-value* } \\
\text { (P-value) }\end{array}$ \\
\hline I am encouraged to participate in class & $3.43 \pm 1.00$ & $6(9.7)$ & $28(45.2)$ & $19(30.6)$ & $5(8.1)$ & $4(6.5)$ & $0.16(0.68)$ \\
\hline $\begin{array}{l}\text { The teaching is sufficient to develop } \\
\text { my confidence }\end{array}$ & $3.27 \pm 0.99$ & $6(9.7)$ & $20(32.3)$ & $24(38.7)$ & $9(14.5)$ & $3(4.8)$ & $0.27(0.60)$ \\
\hline $\begin{array}{l}\text { The teaching encourages me to be an active } \\
\text { learner }\end{array}$ & $3.58 \pm 1.04$ & $12(19.4)$ & $23(37.1)$ & $19(30.6)$ & $5(8.1)$ & $3(4.8)$ & $0.58(0.44)$ \\
\hline The teaching is well focused & $3.45 \pm 0.89$ & $7(11.3)$ & $21(33.9)$ & $30(48.4)$ & $\mathrm{I}(\mathrm{I} .6)$ & $3(4.8)$ & $0.28(0.59)$ \\
\hline $\begin{array}{l}\text { The teaching is sufficient to develop } \\
\text { my competence }\end{array}$ & $3.30 \pm 0.98$ & $7(11.3)$ & $18(29.0)$ & $27(43.5)$ & $7(11.3)$ & $3(4.8)$ & $0.64(0.42)$ \\
\hline $\begin{array}{l}\text { I am clear about the learning objectives of the } \\
\text { course }\end{array}$ & $3.64 \pm 0.95$ & $12(19.4)$ & $23(37.1)$ & $22(35.5)$ & $3(4.8)$ & $2(3.2)$ & $0.36(0.54)$ \\
\hline The teaching is often stimulating & $3.33 \pm 0.97$ & $5(8.1)$ & $23(37.1)$ & $27(43.2)$ & $2(3.2)$ & $5(8.1)$ & $0.09(0.76)$ \\
\hline The teaching time is put to good use & $3.32 \pm 0.95$ & $4(6.5)$ & $24(38.7)$ & $27(43.5)$ & $2(3.2)$ & $5(8.1)$ & $0.49(0.48)$ \\
\hline $\begin{array}{l}\text { Long-term learning is emphasized over short } \\
\text { term }\end{array}$ & $3.25 \pm 1.12$ & $6(9.7)$ & $23(37.1)$ & $22(35.5)$ & $3(4.8)$ & $8(12.9)$ & $0.31(0.57)$ \\
\hline The teaching is too teacher-centered & $2.93 \pm 1.00$ & $4(6.5)$ & $13(2 \mid .0)$ & $24(38.7)$ & $17(27.4)$ & $4(6.5)$ & $0.08(0.77)$ \\
\hline The teaching overemphasizes factual learning & $3.32 \pm 0.67$ & $2(3.2)$ & $20(32.3)$ & $37(59.7)$ & $2(3.2)$ & $\mathrm{I}(\mathrm{I} .6)$ & $0.01(0.89)$ \\
\hline I am encouraged to participate in class & $3.35+0.97$ & $4(6.5)$ & $28(45.2)$ & $20(32.3)$ & $6(9.7)$ & $4(6.5)$ & $0.03(0.85)$ \\
\hline
\end{tabular}

Notes: Overall mean \pm SD was $3.34 \pm 0.17$; total mean score was 40.17 ; *ANOVA significant level 0.05 .

Abbreviations: ANOVA, analysis of variance; SD, standard deviation. 
showed a good mean score, where the highest mean score (4.03) was recorded for "I am confident about passing this year" (79\%). Furthermore, the mean score of "Much of what I have to learn seems relevant to a career in medicine" was 3.85 , the mean score of "I have learned a lot about empathy in my profession" was 3.77 , and a slightly low mean score, that is, 3.09, was recorded for "I am able to memorize all I need" that was statically significant with a $P$-value of 0.02 .

\section{Students' perceptions of atmosphere}

In the SPoA sub-scale, there were 12 items used (Table 4). The score of SPoA ranged from 2.27 to 3.91. The overall mean \pm SD was $3.44 \pm 0.45$. An overall mean score of 12 items about SPoA was 41.32 of 60 , which showed a good perception ( $\sim 68.9 \%)$ about the atmosphere among fifth year medical students. Among most of the participants, 69.4\% agreed (19.4\% strongly agree and 50\% agree) and reported the atmosphere to be relaxed during the lectures. Similarly, $67.8 \%$ of the students reported (3.71 mean score) that "I feel able to ask the questions I want", whereas $74.2 \%$ of the students reported (3.91 mean score) that "I feel comfortable in class socially". Rest of eight items also have good mean scores, except for one item, which had a lower mean score of 2.27 when asked about "I find the experience disappointing"

Table 2 Students' perception of teachers

\begin{tabular}{|c|c|c|c|c|c|c|c|}
\hline Questionnaire & Mean \pm SD & $\begin{array}{l}\text { Strongly } \\
\text { agree, } \\
\text { n (\%) }\end{array}$ & $\begin{array}{l}\text { Agree, } \\
\text { n (\%) }\end{array}$ & $\begin{array}{l}\text { True } \\
\text { sometimes, } \\
\text { n (\%) }\end{array}$ & $\begin{array}{l}\text { Disagree, } \\
\text { n (\%) }\end{array}$ & $\begin{array}{l}\text { Strongly } \\
\text { disagree, } \\
\text { n (\%) }\end{array}$ & $\begin{array}{l}\text { F-value } \\
\text { (P-value)* }\end{array}$ \\
\hline $\begin{array}{l}\text { The teachers are good at providing feedback to } \\
\text { students }\end{array}$ & $3.12 \pm 0.96$ & $3(4.8)$ & $20(32.3)$ & $25(40.3)$ & $10(16.1)$ & $4(6.5)$ & $0.35(0.55)$ \\
\hline $\begin{array}{l}\text { The teachers have good } \\
\text { communications skills with patients }\end{array}$ & $3.62 \pm 0.90$ & II (I7.7) & $22(35.5)$ & $26(4 I .9)$ & $\mathrm{I}(\mathrm{I} .6)$ & $2(3.2)$ & $0.23(0.62)$ \\
\hline The teachers are knowledgeable & $4.01 \pm 0.75$ & $15(24.2)$ & $35(56.5)$ & II (I7.7) & $0(0)$ & $\mathrm{I}(\mathrm{I} .6)$ & $0.24(0.62)$ \\
\hline The teachers give clear examples & $3.77 \pm 0.85$ & $13(21.0)$ & $25(40.3)$ & $22(35.5)$ & $\mathrm{I}(\mathrm{I} .6)$ & $\mathrm{I}(\mathrm{I} .6)$ & $0.20(0.65)$ \\
\hline The teachers are well prepared for their classes & $3.66 \pm 0.97$ & $12(19.4)$ & $24(38.7)$ & $22(35.5)$ & I (I.6) & $3(4.8)$ & $0.04(0.83)$ \\
\hline The teachers provide constructive criticism here & $3.29 \pm 1.03$ & $8(12.9)$ & $17(27.4)$ & $25(40.3)$ & $9(14.5)$ & $3(4.8)$ & $0.01(0.91)$ \\
\hline The teachers ridicule the students & $2.96 \pm 0.92$ & $4(6.5)$ & $9(14.5)$ & $34(54.8)$ & II (I7.7) & $4(6.5)$ & $1.98(0.16)$ \\
\hline The teachers get angry in class & $3.19 \pm 0.82$ & $\mathrm{I}(\mathrm{I} .6)$ & $10(16.1)$ & $23(37.1)$ & $23(37.1)$ & $5(8.1)$ & $2.76(0.10)$ \\
\hline The teachers are authoritarian & $3.19 \pm 0.82$ & $3(4.8)$ & $18(29.0)$ & $30(48.4)$ & $10(16.1)$ & $\mathrm{I}(\mathrm{I} .6)$ & $1.08(0.30)$ \\
\hline The teachers are patient with patients & $3.69 \pm 0.75$ & $8(12.9)$ & $29(46.8)$ & $24(38.7)$ & $0(0)$ & I (I.6) & $0.49(0.48)$ \\
\hline The students irritate the teachers & $2.85 \pm 0.76$ & $0(0)$ & $12(19.4)$ & $31(50)$ & $17(27.4)$ & $2(3.2)$ & $0.005(0.94)$ \\
\hline
\end{tabular}

Notes: Overall mean \pm SD was 3.39 \pm 0.37 ; total mean score was 37.35 ; *ANOVA significant level 0.05 .

Abbreviations: ANOVA, analysis of variance; SD, standard deviation.

Table 3 Students' academic self-perceptions

\begin{tabular}{|c|c|c|c|c|c|c|c|}
\hline Questionnaire & Mean \pm SD & $\begin{array}{l}\text { Strongly } \\
\text { agree, } \\
\text { n (\%) }\end{array}$ & $\begin{array}{l}\text { Agree, } \\
\text { n (\%) }\end{array}$ & $\begin{array}{l}\text { True } \\
\text { sometimes, } \\
\text { n (\%) }\end{array}$ & $\begin{array}{l}\text { Disagree, } \\
\text { n (\%) }\end{array}$ & $\begin{array}{l}\text { Strongly } \\
\text { disagree, } \\
\text { n (\%) }\end{array}$ & $\begin{array}{l}F \text {-value } \\
(P \text {-value)* }\end{array}$ \\
\hline $\begin{array}{l}\text { I am able to memorize all I } \\
\text { need }\end{array}$ & $3.09 \pm 0.93$ & $5(8.1)$ & $12(19.4)$ & $32(51.6)$ & $10(16.1)$ & $3(4.8)$ & $5.31(0.02)$ \\
\hline $\begin{array}{l}\text { Much of what I have to learn } \\
\text { seems relevant to a career in medicine }\end{array}$ & $3.85 \pm 0.92$ & $13(2 \mid)$ & $33(53.2)$ & $13(21)$ & $0(0)$ & $3(4.8)$ & I. $10(0.29)$ \\
\hline $\begin{array}{l}\text { I feel I am being well prepared } \\
\text { for my profession }\end{array}$ & $3.25 \pm 0.92$ & $4(6.5)$ & $21(33.9)$ & $27(43.5)$ & $7(1 \mid .3)$ & $3(4.8)$ & $1.56(0.21)$ \\
\hline $\begin{array}{l}\text { Last year's work has been a } \\
\text { good preparation for this year's work }\end{array}$ & $3.38 \pm 1.01$ & $7(11.3)$ & $23(37.1)$ & $23(37.1)$ & $5(8.1)$ & $4(6.5)$ & $0.003(0.95)$ \\
\hline $\begin{array}{l}\text { My problem-solving skills are } \\
\text { being well developed here }\end{array}$ & $3.50 \pm 0.98$ & $7(11.3)$ & $28(45.2)$ & $20(32.3)$ & $3(4.8)$ & $4(6.5)$ & $0.01(0.89)$ \\
\hline $\begin{array}{l}\text { I am confident about passing } \\
\text { this year }\end{array}$ & $4.03 \pm 0.98$ & $19(30.6)$ & $30(48.4)$ & II (I7.7) & $0(0)$ & $2(3.2)$ & $0.70(0.40)$ \\
\hline $\begin{array}{l}\text { I have learned a lot about } \\
\text { empathy in my profession }\end{array}$ & $3.77 \pm 0.98$ & $12(19.4)$ & $33(53.2)$ & II (I7.7) & $3(4.8)$ & $3(4.8)$ & $2.88(0.09)$ \\
\hline $\begin{array}{l}\text { Learning strategies which } \\
\text { worked for me before continue } \\
\text { to work for me }\end{array}$ & $3.53 \pm 1.05$ & $9(14.5)$ & $28(45.2)$ & $16(25.8)$ & $5(8.1)$ & $4(6.5)$ & $0.14(0.70)$ \\
\hline
\end{tabular}

Notes: Overall mean \pm SD was $3.55 \pm 0.31$; total mean score was $28.4 ; * A N O V A$ significant level 0.05 .

Abbreviations: ANOVA, analysis of variance; SD, standard deviation. 
Table 4 Students' perceptions of atmosphere

\begin{tabular}{|c|c|c|c|c|c|c|c|}
\hline Questionnaire & Mean \pm SD & $\begin{array}{l}\text { Strongly } \\
\text { agree, } \\
\text { n (\%) }\end{array}$ & $\begin{array}{l}\text { Agree, } \\
\text { n (\%) }\end{array}$ & $\begin{array}{l}\text { True } \\
\text { sometimes, } \\
\text { n (\%) }\end{array}$ & $\begin{array}{l}\text { Disagree } \\
\text { n (\%) }\end{array}$ & $\begin{array}{l}\text { Strongly } \\
\text { disagree, } \\
\text { n (\%) } \\
\end{array}$ & $\begin{array}{l}\text { F-value } \\
\text { (P-value)* }\end{array}$ \\
\hline The atmosphere is relaxed during lectures & $3.80 \pm 0.86$ & $12(19.4)$ & $31(50)$ & $15(24.2)$ & $3(4.8)$ & I (I.6) & $0.16(0.68)$ \\
\hline I feel able to ask the questions I want & $3.71 \pm 0.99$ & $12(19.4)$ & $30(48.4)$ & $12(19.4)$ & $6(9.7)$ & $2(3.2)$ & $0.01(0.91)$ \\
\hline I feel comfortable in class socially & $3.91 \pm 0.91$ & $16(25.8)$ & $30(48.4)$ & $13(21.0)$ & I ( $(1.6)$ & $2(3.2)$ & $0.54(0.46)$ \\
\hline $\begin{array}{l}\text { There are opportunities for me to develop } \\
\text { interpersonal skills }\end{array}$ & $3.87 \pm 0.8 \mathrm{I}$ & $13(2 \mid)$ & $31(50)$ & $16(25.8)$ & I ( $(1.6)$ & I (I.6) & $0.48(0.48)$ \\
\hline The atmosphere is relaxed during seminars/tutorials & $3.75 \pm 0.91$ & II (I7.7) & $32(5 I .6)$ & $14(22.6)$ & $3(4.8)$ & $2(3.2)$ & $0.30(0.58)$ \\
\hline $\begin{array}{l}\text { The enjoyment outweighs the stress of } \\
\text { studying medicine }\end{array}$ & $3.30 \pm 1.06$ & $7(11.3)$ & $21(33.9)$ & $23(37.1)$ & $6(9.7)$ & $5(8.1)$ & $0.54(0.46)$ \\
\hline The atmosphere motivates me as a learner & $3.40 \pm 1.12$ & $10(16.1)$ & $22(35.5)$ & $17(27.4)$ & $9(14.5)$ & $4(6.5)$ & $0.55(0.45)$ \\
\hline I am able to concentrate well & $3.53 \pm 0.93$ & $8(12.9)$ & $25(40.3)$ & $24(38.7)$ & $2(3.2)$ & $3(4.8)$ & $1.56(0.21)$ \\
\hline The atmosphere is relaxed during the ward teaching & $3.11 \pm 1.05$ & $6(9.7)$ & $15(24.2)$ & $26(41.9)$ & $10(16.1)$ & $5(8.1)$ & $0.80(0.37)$ \\
\hline This school is well timetabled & $3.32 \pm 1.05$ & $8(12.9)$ & $19(30.6)$ & $24(38.7)$ & $7(11.3)$ & $4(6.5)$ & $0.15(0.69)$ \\
\hline I find the experience disappointing & $2.27 \pm 1.10$ & $3(4.8)$ & $6(9.7)$ & $12(19.4)$ & $25(40.3)$ & $16(25.8)$ & $0.22(0.64)$ \\
\hline Cheating is a problem in this school & $3.35 \pm 1.38$ & $19(30.6)$ & $10(16.1)$ & $13(2 \mid .0)$ & $14(22.6)$ & $6(9.7)$ & $2.39(0.12)$ \\
\hline
\end{tabular}

Notes: Overall mean \pm SD was 3.44 \pm 0.45 ; total mean score was 41.32; *ANOVA significant level 0.05 .

Abbreviations: ANOVA, analysis of variance; SD, standard deviation.

because about $66.1 \%$ disagreed ( $40.3 \%$ disagreed and $25.8 \%$ strongly disagreed), and hence, the students disagreed about it. No significant level was found in SPoA.

\section{Students' social self-perception}

In the SSSA sub-scale, there were 12 items used (Table 5). The score for SSSP ranged from 2.85 to 4.33 . The overall mean \pm SD was $3.47 \pm 0.54$. The total mean score of SSSA was 24.33 of 35 , showing that it has a good perception $(\sim 70 \%)$. The item "I have good friends in this school" had the highest mean score, that is, 4.33. Moreover, two low mean scores were recorded for the item "There is a good support system for students who gets stressed" (2.85) and for the item "I am rarely bored on this course" (2.90). The other questions showed good mean scores.

\section{The overall scores}

The overall score for all five disciplines of DREAM score was $171.57 / 250$, showing that the medical students' perceptions of the educational environment with incorporation of the reformed curriculum at the College of Medicine, KSU, were more positive than negative. The total mean score for the SPoL was $40.17 / 60$, SPoT was $37.35 / 55$, SASP was $28.4 / 40$, SPoA was $41.32 / 60$, and SSSP was $24.33 / 35$. The students' perceptions toward the educational environment were positive for all five DREEM sub-scales.

\section{Discussion}

Educational environments remain imperative to determine the usefulness and success of a medical school curriculum. ${ }^{16}$ Therefore, we aimed to evaluate the educational environment as perceived by the second batch of medical graduates of the College of Medicine, KSU, Riyadh, Saudi Arabia.

In our study, the medical students' perceptions of the educational environment with incorporation of the reformed curriculum at the College of Medicine, KSU, were found to be more positive than negative, as the overall score for all five disciplines of DREAM came out to be 171.57/250.

According to McAleer et al, a mean score between 50 and 100 indicates a serious problem. ${ }^{17}$ In our study, the overall mean DREEM score for all sub-scales was 171.57/250 (68.62\%), which fall well within the range 101-150, being indicative of more positive than the negative perceptions of the environment. ${ }^{18,19}$ This was almost similar to a study at a UK medical school, which has reported an overall mean score of 139/200 (69.5\%). ${ }^{12,19}$ Our overall mean score was found to be higher than that reported for Malaysia, that is, $125.3 / 200(62.65 \%),{ }^{20}$ and Nepal, with scores of 130/200 $(65 \%)$, respectively. ${ }^{21}$

In our study, the mean scores remained indifferent among the male and female participants. This is in contrast with the findings among Nigerian students where the total DREEM scores for males were significantly higher than those for females. ${ }^{17}$

There were three items having scored a mean of more than 4.0 items, "The teachers are knowledgeable" mean score $=4.01$, "I am confident about passing this year" mean score $=4.03$, "I have good friends in this school" mean score $=4.33$. On the other hand, the lowest mean score, that is, 2.27 was found for the item, "I find the experience disappointing". Our findings coincided with those of Nigeria as the lowest scores were recorded for the sub-scale, SPoA, whereas in 
Table 5 Students' social self-perceptions

\begin{tabular}{|c|c|c|c|c|c|c|c|}
\hline Questionnaire & Mean $\pm S D$ & $\begin{array}{l}\text { Strongly } \\
\text { agree, n (\%) }\end{array}$ & $\begin{array}{l}\text { Agree, } \\
\text { n (\%) }\end{array}$ & $\begin{array}{l}\text { True } \\
\text { sometimes, } \mathbf{n}(\%)\end{array}$ & $\begin{array}{l}\text { Disagree, } \\
\text { n (\%) }\end{array}$ & $\begin{array}{l}\text { Strongly } \\
\text { disagree, n (\%) }\end{array}$ & $\begin{array}{l}\text { F-value } \\
\text { (P-value)* }\end{array}$ \\
\hline I have good friends in this school & $4.33 \pm 0.74$ & $28(45.2)$ & $29(46.8)$ & $4(6.5)$ & $0(0)$ & I (I.6) & $0.92(0.33)$ \\
\hline $\begin{array}{l}\text { There is a good support system } \\
\text { for students who gets stressed }\end{array}$ & $2.85 \pm 1.30$ & $8(12.9)$ & $13(2 \mid .0)$ & $14(22.6)$ & $16(25.8)$ & II (I7.7) & $0.002(0.96)$ \\
\hline $\begin{array}{l}\text { I am too tired to enjoy this } \\
\text { course }\end{array}$ & $3.14 \pm 1.11$ & $9(14.5)$ & II (I7.7) & $27(43.5)$ & $10(16.1)$ & $5(8.1)$ & $3.28(0.07)$ \\
\hline I am rarely bored on this course & $2.90 \pm 1.03$ & $4(6.5)$ & $12(19.4)$ & $26(41.9)$ & $14(22.6)$ & $6(9.7)$ & $0.87(0.35)$ \\
\hline My accommodation is pleasant & $3.85 \pm 0.98$ & $19(30.6)$ & $21(33.9)$ & $17(27.4)$ & $4(6.5)$ & I (I.6) & $0.5 \mathrm{I}(0.47)$ \\
\hline My social life is good & $3.80 \pm 1.03$ & $16(25.8)$ & $28(45.2)$ & $10(16.1)$ & $6(9.7)$ & $2(3.2)$ & $2.51(0.11)$ \\
\hline I seldom feel lonely & $3.46 \pm 1.15$ & II (I7.7) & $24(38.7)$ & I5 (24.2) & 7 (II.3) & $5(8.1)$ & $0.28(0.59)$ \\
\hline
\end{tabular}

Notes: Overall mean $\pm S D$ was $3.47 \pm 0.54$; total mean score was 24.33 ; *ANOVA significant level 0.05 . Abbreviations: ANOVA, analysis of variance; SD, standard deviation.

Nepal and in the UK SASP were rated the lowest. Our students also perceived teachers as being knowledgeable, the same finding reported by the students in Nigeria and Nepal. Whereas cheating was identified to be a problem in our school, it was not so in Nigeria and Nepal. Our students felt the same as their counterparts in the Nepal and were happy with the provided accommodation.

We believe that our results may add for a longitudinal excellence for measuring the students' perceptions of the modifications intended concerning the new reformed curriculum at KSU, Saudi Arabia. This study may also serve for other medical colleges in the Kingdom who wish to preevaluate their curriculum reforms.

\section{Study limitations}

This study has been limited to testing the perception of the students regarding the academic environment at the College of Medicine, KSU as the number of participants is not too high. The generalizability could not be achieved as the study was limited to asking students' perception of the College of Medicine, KSU only, yet the findings of the present study still are significant in allowing other medical colleges in the Kingdom to explore more in the same regard.

\section{Conclusion}

We conclude that although the total number of participants in this study is moderately low yet substantial findings were achieved. Developments are needed to be addressed and corrected concerning the perceived problems for some items, especially for the sub-scales SSSP and SPoA. There were three DREEM items that scored low mean scores. Among these three, two items belonged to the SSSP and another to SPoA sub-scale. These low scores suggest that these items should be examined more closely as they indicate problem areas.

\section{Acknowledgments}

The authors wish to thank all the students who took part in answering the questionnaire and helped them identify the pertinent issues related to academic integrity. They also wish to extend their thanks to Mr Arthur Asnani and Mr Tauseef Ahmad who kindly supported with statistics.

\section{Disclosure}

The authors report no conflicts of interest in this work.

\section{References}

1. The Executive Council WFME. International standards in medical education: assessment and accreditation of medical schools' educational programmes. A WFME position paper. Med Educ. 1998;32(5):549-558.

2. Genn JM. AMEE Medical Education Guide No. 23 (Part 2): curriculum, environment, climate quality and change in medical education - a unifying perspective. Med Teach. 2001;23(5):445-454.

3. Roff S, McAleer S. What is educational climate? Med Teach. 2001; 23(4):333-334.

4. Harden RM. The learning environment and the curriculum. Med Teach. 2001;23(4):335-336.

5. Rothman AI, Ayoade F. The development of a learning environment: a questionnaire for use in curriculum evaluation. $J$ Med Educ. 1970;45(10):754-759.

6. Marshall RE. Measuring the medical school learning environment. J Med Educ. 1978;53(2):98-104.

7. Feletti GI, Clarke RM. Review of psychometric features of the medical school learning environment survey. Med Educ. 1981;15(2): 92-96.

8. Moore-West M, Harrington DL, Mennin SP, Kaufman A, Skipper BJ. Distress and attitudes toward the learning environment: effects of a curriculum innovation. Teach Learn Med. 1989;1(3):151-157.

9. General Medical Council. Tomorrow's Doctors. Recommendations on Undergraduate Medical Education. London: General Medical Council; 1993.

10. Chan DS. Combining qualitative and quantitative methods in assessing hospital learning environments. Int J Nurs Stud. 2001;38(4): 447-459.

11. Mulrooney A. Development of an instrument to measure the practice vocational training environment in Ireland. Med Teach. 2005;27(4): 338-342.

12. Roff S, McAleer S, Harden RM, et al. Development and validation of the Dundee Ready Education Environment Measure (DREEM). Med Teach. 1997;19:295-299. 
13. Roff S. The Dundee Ready Educational Environment Measure (DREEM)a generic instrument for measuring students' perceptions of undergraduate health professions curricula. Med Teach. 2005;27(4):322-325.

14. Dimoliatis ID, Vasilaki E, Anastassopoulos P, Ioannidis JP, Roff S. Validation of the Greek translation of the Dundee Ready Education Environment Measure (DREEM). Educ Health (Abingdon). 2010;23(1):348.

15. Pimparyon P, Caleer SM, Pemba S, Roff S. Educational environment, student approaches to learning and academic achievement in a Thai nursing school. Med Teach. 2000;22(4):359-364.

16. Abraham R, Ramnarayan K, Vinod P, Torke S. Students' perceptions of learning environment in an Indian medical school. BMC Med Educ. 2008;8:20

17. Roff S, McAleer S, Ifere OS, Bhattacharya S. A global diagnostic tool for measuring educational environment: comparing Nigeria and Nepal. Med Teach. 2001;23(4):378-382.
18. Jiffry MT, McAleer S, Fernando S, Marasinghe RB. Using the DREEM questionnaire to gather baseline information on an evolving medical school in Sri Lanka. Med Teach. 2005;27(4):348-352.

19. Dunne F, McAleer S, Roff S. Assessment of the undergraduate medical environment in a large UK medical school. Health Educ J. 2006;65(2):149-158.

20. Al-Naggar RA, Abdulghani M, Osman MT, et al. The Malaysia DREEM: perceptions of medical students about the learning environment in a medical school in Malaysia. Adv Med Educ Prac. 2014;5:177-184.

21. McAleer S, Roff S. A practical guide to using the Dundee Ready Education Environment Measure (DREEM). In: Genn JM, editor. $A M E E$ Medical Education Guide No 23 Curriculum, Environment, Climate Quality and Change in Medical Education; A Unifying Perspective. Dundee: Association of Medical Education in Europe; 2001:29-33.
Advances in Medical Education and Practice

\section{Publish your work in this journal}

Advances in Medical Education and Practice is an international, peerreviewed, open access journal that aims to present and publish research on Medical Education covering medical, dental, nursing and allied health care professional education. The journal covers undergraduate education, postgraduate training and continuing medical education

\section{Dovepress}

including emerging trends and innovative models linking education, research, and health care services. The manuscript management system is completely online and includes a very quick and fair peer-review system. Visit http://www.dovepress.com/testimonials.php to read real quotes from published authors.

Submit your manuscript here: http://www.dovepress.com/advances-in-medical-education-and-practice-journal 